\title{
Platão e a poesia de seu tempo: contra Simônides ${ }^{1}$
}

Luiz Roberto TAKayama - Universidade Federal de Lavras

Censurou-se Platão pelo fato de condenar aquilo mesmo a que deve tanto, ele, talvez, mais do que qualquer outro filósofo. Lembram-nos de que, em sua juventude, anteriormente ao seu encontro com Sócrates, ele teria se consagrado com paixão à arte das musas. O recurso aos meios poéticos parece também irrecusável na composição de seus diálogos: aos proêmios, verdadeiras peças dramáticas, vem se acrescentar muitas vezes, como no Fedro, a descrição não menos "poética" dos mitos. A República, em particular, ao ser concluída com o mito de Er logo após ter proclamado o banimento do poeta, parece constituir um bom exemplo para ilustrar essa ambiguidade de Platão no que diz respeito à poesia.

Mais ainda. Após concluir de modo incisivo o processo de condenação da poesia no livro X (606e1-607a8), é o próprio filó-

\footnotetext{
${ }^{1}$ Este artigo retoma, com ligeiras modificações, um dos capítulos da dissertação de mestrado, Sobre a crítica de Platão à poesia, apresentada ao Programa de Pós-Graduação em Filosofia da FFLCH da USP e defendida em abril de 2007, sob a orientação de Franklin de Mattos.
} 
sofo que se apressa em atenuar o tom de sua crítica: "Para não sermos acusados de alguma rudeza ou grosseria, tornemos a lhe dizer que se trata de uma antiga querela (palaiá tis diaphorá) entre filosofia e poesia" (607b) ${ }^{2}$. Como indícios dessa disputa, Platão cita em seguida algumas expressões de fontes incertas e desconhecidas mas que teriam sido supostamente forjadas pelos poetas contra a filosofia: "a cadela ladradora gane contra seu dono"; "aquele estimado como um grande homem nas tagarelices entre os tolos; "a multidão dominando os sábios"; "aqueles que se inquietam com meditações sutis porque têm fome" (607b-d).

Nessas fórmulas pôde-se ver com certa verossimilhança acusações de ateísmo provocadas pelo teor materialista das teorias cosmogônicas dos primeiros filósofos assim como um desprezo por aqueles que se proclamavam superiores por discutir questões fúteis que serviam apenas para encobrir sua existência miserável ${ }^{3}$. No sentido oposto, embora não explicitado por Platão, sabe-se que alguns filósofos, muito antes do fundador da Academia, já não poupavam críticas aos poetas e à poesia. Conta-se que Pitágoras, quando de sua descida ao Hades, lá teria encontrado as almas de Hesíodo e de Homero sendo duramente castigadas por terem blasfemado contra os deuses (Laércio, 1988, p. 293) ${ }^{4}$.

${ }^{2}$ Para o livro X da República de Platão utilizamos a tradução de Lopes (2002), para os demais livros, a de Prado (2009)

${ }^{3}$ Sobre uma exposição mais detalhada das prováveis fontes e interpretações dessas citações, ver: Colin (1928, pp. 27-28) e Halliwell (1988, p. 155)

${ }^{4}$ Segundo outras fontes, os primeiros discípulos de Pitágoras teriam tentado proscrever tanto a Ilíada quanto a Odisséia devido ao caráter ultrajante de suas descrições dos deuses; no entanto, não logrando êxito na extirpação dos poemas homéricos fortemente ancorados na tradição, passaram a praticar uma interpretação alegórica dos mesmos (Duchemin, 1955, p. 18). 
Heráclito, por sua vez, teria dito que Homero e Arquíloco deviam ser expulsos dos concursos poéticos e surrados com varas (Ibid., p. 251). Mas, dentre os pré-socráticos, é a Xenófanes que se atribuem os ataques mais contundentes contra a imoralidade dos deuses e a natureza antropomórfica que a religião convencional lhes conferia: segundo Clemente de Alexandria, o filósofo teria afirmado que se fosse dada aos animais a capacidade de desenharem, eles teriam feito os deuses à semelhança de suas próprias formas; e de acordo com Sexto Empírico, Xenófanes teria acusado Homero e Hesíodo de terem conferido aos deuses "tudo quanto entre os homens é vergonhoso e censurável, roubos, adultérios e mentiras recíprocas" (Kirk; Raven, 1990, p. 169). Ora, tais censuras, ao incidirem fundamentalmente sobre a imagem infame que os poetas apresentavam dos deuses, antecipam de maneira notável o caráter teológico-moral assumido pela crítica que Platão realizará nos segundo e terceiro livros da República.

Entretanto, se o filósofo ateniense não foi o iniciador, mas, antes, o herdeiro dessa divergência de longa data, é preciso acrescentar que ele amplificou tal legado a uma ordem de grandeza jamais vista até então. Cobrindo os aspectos teológico, metafísico, epistemológico, psicológico e ético no horizonte de uma pedagogia responsável pela formação do cidadão grego, Platão desfere, assim, os mais duros golpes contra a poesia na República. Porém, a amplitude e mesmo a contundência dessa condenação não são suficientes para apagar totalmente os traços de uma antiga e intensa afeição: "se a poesia e a imitação que visam o prazer apresentassem algum argumento sobre a necessidade de tê-la na cidade bem legislada, nós a admitiríamos de bom grado, pois temos a ciência de que estamos sob seu encantamento" (Re- 
pública, X, 607c).

Collingwood chega mesmo a dizer que essa antiga querela entre poesia e filosofia, se existiu de fato alguma, se encontraria antes no coração de Platão: o "calor" com que se revestem suas críticas à arte de Homero corresponderia, assim, na mesma medida, à dimensão de sua afeição por ela, e que, portanto, não era pouca ${ }^{5}$. Esse sentimento, aliás, o próprio filósofo o revela no interior mesmo do livro X da República:

Mas se não, meu caro amigo, assim como os amantes, quando consideram que o amor não mais traz benefícios, se separam mesmo que forçadamente, da mesma forma também nós, por ter-nos sido engendrado um amor de tal poesia pelo regime dos belos governos, aceitaremos de bom grado que ela nos mostre ser a melhor e a mais verdadeira; mas enquanto não for capaz de se defender, a escutaremos cantando em contrapartida para nós mesmos esse argumento que dissemos desse canto, tendo precaução para não cairmos novamente na infantilidade e no amor próprio à maioria. (607e-608a).

Além disso, Platão parece se valer, na composição de sua obra, daquela mesma mimésis dramática que condenava no livro III. Com efeito, fazendo uso frequente do discurso direto, "escondendo-se" atrás dos personagens que faz falar em seu lugar, o filósofo, no campo da composição literária (léxis), seria, segundo sua própria definição, muito mais "imitador" do que

5"A 'antiga querela entre filosofia e poesia' deve ser procurada não na história mais antiga do pensamento grego, onde seus traços são, na melhor das hipóteses, escassos, mas na própria vida de Platão." (Collingwood, 1925, pp. 169-170) 
Homero. Todavia, é preciso observar que Platão não faz poesia, mas cria um novo modo de expressão sobre o qual ela certamente tem grande influência - basta nos lembramos de que a célebre palinódia de Sócrates no Fedro pode ser considerada, a justo título, um discurso de inspiração poética, tal como o comprovam sua composição bem como sua associação ao poeta Estesícoro. Mas, se o recurso aos meios poéticos não faz de Platão um poeta, não se pode deixar de notar o parentesco interno da poesia com essa nova forma de arte que ele inventava com seus diálogos. Para Nietzsche, foi "por necessidades inteiramente artísticas" que Platão precisou criar uma nova "forma de arte" aparentada com aquelas formas que repelia.

Se a tragédia havia absorvido em si todo os gêneros de arte anteriores, cabe dizer o mesmo, por sua vez, do diálogo platônico, o qual, nascido, por mistura, de todos os estilos e formas precedentes, paira no meio, entre narrativa, lírica e drama, entre prosa e poesia (...). O diálogo platônico foi, por assim dizer, o bote em que a velha poesia naufragante se salvou com todos os seus filhos (Nietzsche, 1992, pp. 88-89).

A análise de Nietzsche se realiza, ao que parece, fundamentalmente sob o ponto de vista estético, ou seja, no campo das necessidades artísticas, como ele mesmo diz. É nessa perspectiva que o diálogo platônico será concebido por ele como o protótipo do romance, como uma espécie de fábula esópica amplificada. Entretanto, mais do que um gênero literário entre outros, a poesia, notadamente a de Homero, ocupava tradicionalmente um lugar de primeira ordem na educação da Grécia antiga. Mais do que uma forma de arte, tratava-se antes de um fenômeno 
sócio-cultural, verdadeira instituição responsável pela formação do homem grego (Havelock, 1996, pp. 79-104)

É assim que Platão condena a poesia, mas tal condenação, não se deve esquecer, se não é sumária, tampouco é absoluta: nem toda poesia deve ser banida da cidade, serão admitidos "os hinos aos deuses (húmnous theois) e os encômios aos homens bons (enkómia tois agatois)" (República, X, 607a) ${ }^{6}$. Há quem veja nessa estranha reserva uma clara referência a Píndaro (Duchemin, 1955, p. 19); todavia, como o próprio Aristóteles já indicava na Poética (4, 48 b 24-27) é provável que o filósofo mirasse mais longe, a saber, nas formas mais primitivas do dizer poético. Com efeito, essa dupla dimensão da poesia aludida aqui por Platão, o canto aos deuses e o louvor aos homens bons, tinha já uma longa tradição atrás de si, correspondendo à dupla função desempenhada pela palavra cantada do poeta na época micênica e também no período arcaico.

Tradicionalmente, a função do poeta é dupla: "celebrar os Imortais, celebrar as façanhas dos homens corajosos." (...) O primeiro fato notável é, pois, a dualidade da poesia: palavra que celebra, ao mesmo tempo, o feito humano e palavra que conta a história dos deuses (Detienne, 1988, p. 17).

Esse duplo registro da palavra poética estaria relacionado, segundo Detienne, às duas ordens em torno das quais se organizava o sistema palaciano da época: uma esfera do rei todopoderoso, que concentrava as funções religiosas, econômicas e

\footnotetext{
${ }^{6}$ Para Goldschnidt (1970, p. 104), a admissão dessas duas formas poéticas, cujos elementos imitativos e narrativos se verão reduzidos, traduz a concepção rigorosa de Platão segundo a qual nenhuma representação, nenhuma imagem pode ser dada da "Divindade em sua essência pura".
} 
políticas; e uma casta guerreira comandada pelo "chefe do Laos". No primeiro sentido, as teogonias narradas pelo poeta seriam inseparáveis dos mitos de soberania e de emergência, que alçavam ao primeiro plano a figura de um rei-divino responsável pela instauração da ordem no Cosmos: "Nesse nível, o poeta é antes de tudo um 'funcionário da soberania': recitando o mito de emergência, colabora diretamente com a ordenação mundo" (Detienne, 1988, p. 18). No segundo registro, a palavra do poeta estaria inteiramente voltada a louvar as façanhas ilustres dos guerreiros. Detienne mostra que, numa sociedade guerreira como Esparta antiga, sociedade agonística de iguais (homoioi), predominava uma espécie de "tirania do olhar" que interditava a experiência de uma consciência interiorizada de si mesmo. Num lugar onde cada um só existe e se reconhece através do olhar do outro, a experiência de um moi, de uma consciência de si, se é que ainda podemos chamá-la assim, se organizava, como mostra Vernant, de modo bastante diferente daquela que temos hoje:

O moi não é delimitado nem unificado: é um campo aberto de forças múltiplas (...). Sobretudo, essa experiência é orientada para fora e não para dentro. $\mathrm{O}$ indivíduo se busca e se acha no outro, nesses espelhos refletindo sua imagem que são, cada um, seu $a l$ ter ego, parentes, filhos, amigos. (...) O indivíduo se projeta também e se objetiva no que ele cumpre efetivamente, no que ele realiza: atividades ou obras que lhe permitem de se apreender, não em potência, mas em ato, enérgeia, e que não estão jamais em sua consciência. Não há introspecção. O sujeito não constitui um mundo interior fechado no qual ele deve penetrar para se encontrar ou então, se descobrir. O sujeito é 
extrovertido. Da mesma forma que o olhos não veem a si mesmos, o indivíduo, para se apreender, olha para alhures, para fora. Sua consciência de si não é reflexiva, redobrada sobre si, fechamento interior, face à face com sua própria pessoa: ela é existencial (Vernant, 1989, pp. 224-225).

Diante de um tal quadro, em que prima a exterioridade, o louvor ou a censura trazidos pela palavra do poeta eram decisivos na vida do guerreiro. Nesse meio singular, a palavra do poeta que canta a façanha do guerreiro, é aquela mesma que o "realiza", que lhe confere sua própria existência, ou seja, que o torna digno de ser louvado (aoídimos) e o faz conquistar a glória imortal (kléos áphthiton) através, sobretudo, da bela morte (textitkalòs thánatos), alcançada no campo de batalha.

Existir, quer se esteja vivo ou morto, é se encontrar reconhecido, estimado, honrado; é, sobretudo, ser glorificado, ser objeto de uma palavra de louvor, tornar-se aoídimos, digno de um canto que conta, num gesto sem cessar retomado e repetido, um destino admirado por todos. Pela glória que ele soube conquistar ao entregar sua vida ao combate, o herói inscreve na memória coletiva sua realidade de sujeito individual, exprimindo-se numa biografia que a morte, ao acabá-la, torna inalterável (Vernant, 1989, p. 93).

Se o guerreiro arcaico não pode se reconhecer a si mesmo como sendo o agente de seus próprios atos é porque, num duplo sentido, seu "ser" não lhe pertence:

Sua vitória é puro favor dos deuses, e a façanha, uma vez levada a cabo, toma forma somente através da pa- 
lavra de louvor. Definitivamente, um homem vale o mesmo que seu logos. São os senhores do Louvor, os serventes das Musas que decidem sobre o valor de um guerreiro; são eles que concedem ou negam a 'Memória' (Detienne, 1988, p. 19).

A palavra do poeta, como a do rei e do adivinho, é uma palavra eficaz: palavra que "realiza" (textitkraínei), que instaura o real, que não se separa de sua própria realização; palavra que é, antes de tudo, uma "potência", uma "força" ou uma "ação" que produz Alétheia, ou então, Lethé (Detienne, 1988, p. 36). Mas aqui, como adverte Detienne, a verdade não se opõe ao falso nem à mentira. O canto do poeta é inspirado pelas Musas, filhas de Mnemosyne, mas essa memória sacralizada nada teria a ver com a rememoração ordinária; ela é, em primeiro lugar, de caráter divinatório como o saber mântico, palavra mágicoreligiosa; é ela que concede o dom de vidência ao poeta, que lhe abre acesso ao "outro mundo" para decifrar o "invisível", "o que é, o que será e o que foi" (Detienne, 1988, p. 17). Mas, ela é também a palavra eficaz que concede a glória imortal ao guerreiro, ou seja, seu valor, sua razão de ser, sua própria existência. Nesse plano, a luz da verdade como memória eterna se define em oposição à noite do esquecimento e à obscuridade do silêncio e da morte: a façanha não cantada morre junto do guerreiro que jamais existirá; o silêncio do poeta constitui, portanto, sua extrema censura. "Numa cultura como aquela da Grécia arcaica, onde cada um existe em função de outrem, pelo olhar e através dos olhos dos outros, a verdadeira, a única morte é o esquecimento, o silêncio, a obscura indignidade". (Vernant, 1989, p. 93).

Contudo, as diversas figuras que se associam às duas potên- 
cias complexas da Alétheia e da Lethé não permitem que se as conceba unicamente como contraditórias. Como sublinha Detienne, a palavra eficaz do poeta traz a marca da ambiguidade: se, sob um aspecto, o esquecimento se opõe a memória como a censura ao louvor, por outro eles são complementares, e não podem ser concebidos separadamente. Assim, ao celebrar os deuses bem-aventurados e louvar as façanhas dos guerreiros, a memória do poeta provoca, ao mesmo tempo, um outro tipo de esquecimento, dessa vez salutar, pois é aquele que afasta as misérias e os sofrimentos da vida quotidiana. Segundo outra perspectiva, a ambiguidade da palavra torna-se ainda mais marcante: se o poder de persuasão e sedução, Peithó e Apaté, são indispensáveis à configuração da Alétheia, constituindo, sob o signo de Afrodite, seu aspecto positivo e benéfico, eles também assumem um sentido negativo ao se submeterem à potência noturna de Hermes, conferindo à palavra o poder maléfico de enganar (lógoi pseudeis).

Não há, portanto, de um lado Alétheia $(+)$ e de outro Lethé (-), mas entre estes dois pólos, desenvolve-se uma zona intermediária, na qual a Alétheia desloca progressivamente em direção a Lethé, e assim reciprocamente. A "negatividade" não está, pois, isolada, colocada à parte do Ser; ela é um desdobramento da "Verdade", ela é sua sombra inseparável. As duas potências antitéticas não são, portanto, contraditórias, tendem uma à outra; o positivo tende ao negativo, que, de certo modo, "o nega", mas sem o qual não se sustenta (Detienne, 1988, p. 41).

Eficaz e ambígua, a palavra inspirada do poeta antigo se ar- 
ticula num sistema de pensamento que responde a uma certa prática social e política não mais vigente na pólis clássica. O "conservadorismo" manifesto de Platão na escolha das duas únicas formas de poesia que julga aceitável - formas tradicionais, como vimos, legadas por um passado distante -, talvez possa ser considerado como mais um caso das "tendências arcaizantes" que Schuhl encontra na filosofia platônica. Em seu livro Platão $e$ a arte de seu tempo, o autor procura mostrar que a hostilidade do filósofo em relação às chamadas artes plásticas - tal como praticada em relação à pintura no livro X da República dirigia-se não a toda a arte em geral, mas somente à arte de seu tempo, caracterizada por um novo estilo "ilusionista" que começava a vigorar em sua época; por outro lado, observa o mesmo autor, Platão não escondia sua admiração por uma arte mais antiga, conservadora, hierática, imutável, canonicamente fixada como a arte do Egito:

Lá, diz o ateniense das Leis, promulga-se uma lista descritiva das melhores obras expostas nos templos; não era permitido, nem é agora permitido, aos pintores e a qualquer um dos que executam figuras, quaisquer que elas sejam, inovar nem imaginar algo que não seja conforme à tradição ancestral. O observador lá encontrará objetos pintados ou modelados há dez mil anos - e se digo dez mil anos, prossegue, não se trata de uma frase feita, mas da estrita verdade: estes objetos não são nem mais belos nem mais feios que os de hoje, eles são executados de acordo com as mesmas regras. (Leis, II, 656e) ${ }^{7}$.

\footnotetext{
${ }^{7}$ Traduzido por Schuhl (2010, p. 36).
} 
Como observa Joly (1994, p. 17), acompanhando as análises de Schuhl, é bem possível que "as tendências 'arcaizantes' da filosofia platônica se expliquem menos por um suposto conservadorismo do que por um misoneísmo declarado por parte do filósofo". Sua "neofobia" se identificaria assim à sua aversão a todo tipo de mudança ou inovação, quer no domínio médico, político, psicológico, artístico ou teológico, confundida sempre com decadência e corrupção (República, II, 380e-381d). Sob essa perspectiva, seria interessante investigar se o arcaísmo de Platão em relação à poesia, não poderia ser também a expressão de seu profundo misoneísmo em relação à "nova" poesia de seu tempo.

Um primeiro testemunho da situação e do estatuto da poesia na sociedade a que Platão pertencia nos é dado pelo próprio filósofo, sobretudo no primeiro livro da República. A cultura do homem médio ateniense estava fundada em máximas extraídas dos dizeres dos poetas e que compunham todo um saber prático e ético - é o que bem parecem mostrar os primeiros personagens postos em cena no diálogo. Assim, a discussão se inicia a partir da definição de justiça dada por Céfalo e, logo depois, aperfeiçoada por Polemarco, sob a autoridade de um poeta citado nominalmente por Platão: trata-se de Simônides de Ceos. A dialética socrática vai se confrontar de maneira impiedosa com a máxima ensinada pelo poeta, e as conclusões estapafúrdias que dela serão deduzidas podem ser consideradas como o início, ainda que indireto, do processo de condenação que Platão vai submeter a poesia de uma forma geral. Mas, essa primeira defrontação, não seria possível pensá-la como sendo o indício de uma contenda mais singular? Além da epopeia, da tragédia e da comédia, não haveríamos também de incluir a lírica como 
mais um alvo da crítica de Platão à poesia? Não seria possível considerar Simônides como o grande representante de uma "nova" forma de se fazer e de se entender a poesia contra a qual se volta o "conservadorismo" ou a "neofobia" de Platão?

A crer em Detienne (1988, p. 56), "Simônides de Ceos marca uma virada na tradição poética, ao mesmo tempo, pelo tipo de homem que inova e pela concepção que tem de sua própria arte"; desse modo, o poeta seria peça-chave no processo de secularização ou de dessacralização da palavra poética ocorrido na passagem do período arcaico ao período clássico da Grécia antiga. De acordo com Galí (1999, p. 141), "figura inovadora no marco da cultura grega, o novum que Simônides representa não se deve tanto ao estilo de sua produção poética quanto às notícias que sobre ele nos foram transmitidas" 8 . Com efeito, é através de um corpus anedótico composto pelos diversos testemunhos existentes acerca do poeta que se pode afirmar ser Simônides o primeiro a fazer da poesia uma techné como a pintura ou a escultura, rompendo, assim, radicalmente com a antiga tradição sagrada da poesia.

Segundo um comentário antigo, Píndaro teria censurado Simônides por ter sido este o responsável por tornar a Musa "mercenária" (ergásis) e "amiga do dinheiro" (philokerdés): seria ele o pioneiro na composição de poemas por "encomenda" em troca de uma soma em dinheiro (Edmonds, 1952, p. 247). Fato notável, pois implica numa nova concepção do fazer poético no qual se estabelece, entre outras coisas, uma inédita e inovadora relação entre o poeta e seu "cliente". Nos tempos antigos de uma

\footnotetext{
${ }^{8}$ Por esse motivo deixamos de lado a análise da obra propriamente dita de Simônides, inclusive a do principal fragmento sobre a "filosofia moral" do poeta reproduzido no Protágoras de Platão. A esse respeito, cf. Thayer (1975).
} 
Grécia pré-monetária, o poeta ou aedo não era, propriamente falando, remunerado pelo que fazia; "funcionário da soberania" e membro da corte, o rei o presenteava com objetos dotados de um valor simbólico, segundo a instituição tradicional do dom e do contra-dom (Galí, 1999, p. 143). Ora, a nova relação contratual e comercial que Simônides começa a instituir só pôde ser possível, evidentemente, dentro do quadro histórico no qual se desenvolvia uma economia monetária e mercantil.

A nova riqueza em dinheiro favorece as artes em geral, escultura, pintura e poesia. A política cultural das tiranias e a rivalidade entre os que dispunham de riqueza afetam diretamente a situação das artes. (...) Os tiranos, particularmente afeitos a uma política de ostentação, embelezam suas cidades com monumentos e chamam a suas cortes os profissionais do verso, criando assim a figura do poeta cortesão, cujo exemplo mais genuíno é Anacreonte. Simônides é um poeta itinerante que desenvolve grande parte de sua atividade profissional sob amparo e às expensas de distintos tiranos (...) Não é um poeta integrado em sua comunidade, senão um profissional ambulante que vende sua mercadoria e se esforça por conseguir a remuneração adequada (Galí, 1999, pp. 144-145).

Sob esse aspecto, Simônides parece mesmo ter se esmerado, alcançando grande êxito no comércio de seus produtos; dono de uma fortuna considerável, sua avareza e cobiça tornaramse célebres: a seus amigos que o acusavam de ser um homem avaro, conta Plutarco, Simônides dizia que "o prazer de fazer dinheiro era o único que havia deixado para cuidar em sua velhice"; 
nessa mesma linha, segundo o que narra Estobeu em sua Antologia, ao ser inquirido sobre a razão de tanto zelo por dinheiro estando já em idade avançada, o poeta teria respondido: "É porque prefiro deixar dinheiro para os inimigos quando morrer do que precisar de amigos enquanto viver; pois sei muito bem quão poucas amizades se mantêm" (Edmonds, 1952, p. 253); por sua vez, Aristóteles conta que, numa palestra com a esposa de um tirano, Simônides teria sustentado ser a riqueza superior à sabedoria, pois notava que "os sábios viviam sentados na soleira das casas dos ricos" (Edmonds, 1952, p. 261); noutra passagem, é o mesmo Aristóteles quem nos informa ter sido o poeta contratado por um certo Anaxilau, tirano de Regio, para a composição de um epinício ${ }^{9}$ em sua homenagem, por ocasião de sua vitória na corrida de carro com mulas; em virtude da baixa remuneração proposta, o poeta teria se recusado a executar o serviço sob pretexto de que não era possível escrever em honra a pouco prestigiosas mulas; porém, tendo o tirano aumentado consideravelmente o valor de sua oferta, acaba compondo a ode, sem, contudo, comprometer o que dissera: com efeito, as mulas de Anaxilau, transformam-se, sob a pena do poeta, nas "filhas dos cavalos de pés de tormenta", sem deixarem de ser, como Aristóteles acrescenta jocosamente, igualmente "filhas de asnos" (Edmonds, 1952, p. 309).

Ao compor poemas sob encomenda, o poeta profissional se vê obrigado a modelar seus versos de acordo com as exigências de seu contratante: cabe a ele, portanto, fazer parecer grande o que é pequeno ou então fazer parecer belo o que é, na verdade,

\footnotetext{
${ }^{9}$ Gênero literário composto de odes comemorativas ou canções de triunfo consagradas aos vencedores dos Jogos; se tal gênero não foi criado por Simônides, ele certamente ajudou a criá-lo, tornando-se um expoente na sua composição juntamente com Píndaro.
} 
feio; é essa habilidade que garante o valor de sua mercadoria. Visto desse modo, o poeta comerciante não coloca no mercado seus produtos já acabados mas vende seus serviços, ou seja, sua sophia entendida como excelência na arte (techné) de fazer poesia $^{10}$. Essa habilidade, como mostra Galí, devidamente paga em "capital monetário", consiste em manipular um "capital de imagens" a fim de tornar "memoráveis" as ações de seu cliente, mesmo que estas possuam pouco valor intrínseco como o feito de Anaxilau.

Do mesmo modo que a moeda pode manipular o sentido tradicional dos valores, a imagem poética pode manipular a ordem e o valor tradicional da memória e de seus conteúdos. A imagem poética como monetarização da memória converte a glória, de valor de uso, em valor de troca: o dinheiro dá valor às coisas independentemente de seu valor de uso, da mesma maneira que o poeta dá valor a ações com relativa independência dos prestígios da tradição (Galí, 1999, p. 154).

Ruptura radical, portanto, com a memória antiga tradicional, entendida como a glória imortal trazida pela palavra do poeta ao celebrar a façanha do guerreiro. Mas, num outro sentido, ruptura também com a memória arcaica sacralizada que, como vimos, permitia ao poeta inspirado o acesso à verdade, ou seja,

\footnotetext{
10“A sabedoria, nas artes, é atribuída aos seus mais perfeitos expoentes, por exemplo, a Fídias como escultor e a Policleto como retratista em pedra; e por sabedoria, aqui, não entendemos outra coisa senão a excelência na arte" (Aristóteles, 1991, p. 105). Sobre outros aspectos da sophia de Simônides, cf. Thayer (1975, p. 6-10).
} 
ao conhecimento do passado, do presente e do futuro. Isso porque, como nos conta Cícero, é a Simônides que se deve uma outra importante inovação:

Sou grato a Simônides de Ceos por sua invenção - se foi mesmo dele - da arte da memória (artem memoriae). Pois, diz uma história que, um dia, quando Simônides estava ceando em Cranon na Tessália com um nobre abastado chamado Escopas e tendo cantado uma canção que havia escrito em sua honra contendo por meio de ornamento poético muitas referências a Castor e a Polux, Escopas, de maneira mesquinha, disse que deveria pagar ao poeta somente a metade do preço combinado e que, se ele quisesse, deveria pedir o resto às preciosas deidades que haviam recebido metade de seus elogios. Logo depois, tendo recebido uma mensagem de que dois jovens queriam vê-lo urgentemente, Simônides levanta-se da mesa e se dirige à porta sem, no entanto, encontrar ninguém. Nesse mesmo momento, a sala de refeições de Escopas desaba pondo fim à sua vida e a dos que estavam com ele. Quando seus parentes quiseram enterrá-los, viram que era impossível reconhecer os cadáveres. Mas, conta-se que Simônides foi capaz de identificá-los, pois se lembrava do lugar na mesa que cada convidado ocupava. Foi isso, dizem, que o conduziu à sua descoberta de que o que mais ajuda a memória é o arranjo (Edmonds, 1952, p. 307).

Ou então, como observa Longino o retórico, "comparar imagens (eidolon) e localidades a fim de lembrar nomes e eventos" 
(Edmonds, 1952, p. 267). Com Simônides, a memória, tradicionalmente concebida como um dom sagrado, um saber privilegiado, torna-se técnica de memorização ou, como diz Detienne (1988, p. 57), "técnica secularizada" composta de regras "ao alcance de todos" que integrava o aprendizado de uma techné poética encarada como atividade profissional.

A esse mesmo processo de laicização da poesia concorre igualmente outra contribuição trazida por Simônides, a saber, a introdução de algumas letras no alfabeto grego para o aprimoramento da notação escrita ${ }^{11}$. Ora, essa preocupação do poeta traz à tona um dado bastante significativo: o fato de a obra poética ser escrita e não mais somente recitada; para Galí, trata-se mesmo do principal fator que, de Homero a Simônides, explicaria a transformação ocorrida no estatuto da função poética. Como havia notado Havelock (1996), a passagem de uma cultura de tradição oral a outra dominada pela escrita não significou apenas a substituição de um modo de expressão por outro, senão, mais profundamente, implicou na emergência de uma nova mentalidade, determinando o próprio conteúdo do que era expresso. Assim, o surgimento da escrita tornou possível o aparecimento da prosa, destituindo paulatinamente a recitação poética e seus recursos mnemônicos como meio de preservação e transmissão da tradição: passo fundamental para a conversão da poesia em "literatura"; com a escrita, o discurso falado - evento acústico transcorrido no tempo - passa a se referir a algo que lhe é exterior, de caráter visual e fixado no espaço: "premissa básica para o nascimento não só de uma literatura, como também de

${ }^{11}$ Segundo o Lexicon de Suidas, Simônides teria inventado as vogais abertas eta e omega, assim como as consoantes xi e psi. (Edmonds, 1952, p. 249). 
um pensamento teórico sobre ela" (Galí, 1999, p. 39). Pois é com a palavra escrita que se permite uma separação ou um distanciamento entre a mensagem emitida e o emissor, algo impraticável no processo de identificação "empática" ocorrido na declamação poética (Havelock, 1996, p. 61); ora, esse distanciamento é também aquilo que possibilita a emergência de um autor em relação à sua obra, de um poeta profissional em relação ao poema-mercadoria que comercializa. Por conseguinte, é a escrita que prepara, em grande medida, o terreno para as inovações de Simônides: sob essa nova condição, a objetivação visual e espacial da poesia abre já o caminho que a levará ao encontro de uma atividade com a qual, tradicionalmente, possuía pouca ou nenhuma afinidade.

Segundo a fórmula que Miguel Psellos atribui a Simônides, "a palavra (lógos) é a imagem (eikón) das coisas (ton pragmáton)" (Edmonds, 1952, p. 259). Como observa Detienne (1988, p. 57), eikón é o termo técnico utilizado para designar a "representação figurada" criada pelo pintor ou pelo escultor ${ }^{12}$. Além disso, essa identidade entre a palavra e a imagem se vê reforçada pela famosa definição dada pelo poeta, inspiradora do não menos famoso topos horaciano da ut pictura poesis: de acordo com o que nos informa Plutarco, "Simônides chama a pintura uma poesia silenciosa e a poesia, uma pintura que fala" (Edmonds, 1952, p. 259). É provável, como observa Galí (1999, p. 172), que o fato de os verbos escrever e pintar serem designados, em grego, pelo mesmo vocábulo (graphó) tenha contribuído para essa assimilação; por outro lado, como mostra Thayer (1975,

${ }^{12}$ Sobre a noção de representação figurada como categoria histórica, ver os dois primeiros capítulos dedicados à questão da imagem em Vernant (2002, pp. 295-322). 
pp. 12-13), essas considerações "teóricas" do poeta sobre sua arte refletem, de algum modo, uma característica marcante de sua própria práxis: a força pictórica de suas imagens poéticas. De qualquer maneira, talvez seja esse cotejo inédito entre poesia e pintura realizado por Simônides - e que será retomado, não por acaso, por Platão - o sinal mais revelador de sua concepção inovadora da atividade poética como techné.

Mas se, por um lado, a poesia se desfaz de seu halo sagrado tradicional ao equiparar-se a um trabalho meramente humano e artesanal, por outro, é digno de nota o esforço do poeta profissional em não deixar perder de vista seu elo com o passado: dessa maneira, procura ainda usufruir do prestígio que lhe conferia a tradição, agregando mais valor à sua mercadoria ao mesmo tempo em que pretende marcar a superioridade de sua arte em relação às demais. É assim que Píndaro se proclama "profeta sacerdote" e Baquílides, "divino profeta das Musas" (Galí, 1999, p. 150); em um dos fragmentos da Antologia Palatina, vemos Simônides, por sua vez, invocar a Musa num hexâmetro de estilo homérico: "Canta-me, Musa, o filho de Alcmena de belos tornozelos" (Galí, 1999, p. 32). Como mostra Detienne, na época clássica, o sistema de pensamento que correspondia à função religiosa e à função de louvor da palavra do poeta constituía um "anacronismo"; a glória imortal concedida tradicionalmente pelos seus cantos ao guerreiro valoroso, ele agora a negocia com outra "clientela".

O poeta passa a ter apenas a missão de exaltar os nobres, de louvar os ricos proprietários que desenvolvem uma economia de luxo, de gastos suntuários, que se orgulham de suas alianças matrimoniais e se envaidecem com suas quadrigas ou suas proezas atléticas. A 
serviço de uma nobreza cada vez mais ávida de louvores, na proporção em que suas prerrogativas políticas são contestadas, o poeta reafirma os valores essenciais de sua função; mas isso é feito cada vez mais com tanto esplendor, que tais valores começam a parecer antiquados e, na cidade grega, deixa de haver lugar para este tipo de palavra mágico-religiosa, na medida em que este sistema de valores é condenado pela democracia clássica. No máximo, o poeta não é mais que um parasita, encarregado de devolver à elite que o sustenta uma imagem embelecida de seu passado (Detienne, 1988, pp. 22-23).

Comparável à pintura, a poesia dessacralizada se afirma enquanto techné que produz imagens, na medida em que a palavra é a imagem da coisa; mas, além disso, trata-se de imagens "embelezadas", de imagens comprometidas antes com a apaté esfera da ilusão e do engano, mundo da doxa em ruptura com a alétheia tradicional do poeta antigo inspirado. Com Simônides, a poesia torna-se, como a pintura, uma arte da ilusão, uma arte de enganar. De acordo com o que narra Plutarco, perguntado certa vez sobre a razão de serem os tessálios os únicos que não conseguia enganar, o poeta teria respondido: "é porque eles são demasiado ignorantes para serem enganados por mim" (Edmonds, 1952, p. 257). Ora, como explica Detienne, "desta anedota, que alguns quiseram atribuir a Górgias, deduz-se claramente que os Antigos tratavam a poesia de Simônides como uma arte de engano, como uma forma de expressão onde a apaté era um valor positivo" (Detienne, 1988, p. 57).

Pois é nesse mesmo domínio da apaté que o poeta vai reivindicar a doxa em oposição a alétheia, configurando assim, pela 
primeira vez, um confronto dos mais decisivos para a história da filosofia grega. Ora, esse confronto é aquele mesmo que se encontra no cerne de um problema crucial levantado pela República. A jovem alma, diz Adimanto a Sócrates, após ter ouvido tantos discursos sobre a justiça e a injustiça, bem como as vantagens e as desvantagens de cada uma delas, encontra-se finalmente naquela encruzilhada cantada por Píndaro: "Ou pela via da justiça (dikai) ou pela dos enganos (skoliais apatais) a mais alta muralha tendo escalado, com essa proteção à minha volta, passarei a minha vida?" (365b) A alternativa entre a diké e a apaté, ou seja, entre "ser" justo e "parecer" justo, se reafirma na escolha que, segundo Adimanto, o jovem se vê inclinado a fazer: "Então, já que o parecer (dokein), como me mostram os sábios, até sobre a verdade faz violência (kaì tàn alátheian biatai) e dele depende a felicidade, é absolutamente para esse lado que se deve voltar" (365c). Ora, tais "sábios", evocados aqui anonimamente por Platão, é uma referência direta a Simônides, uma vez que é exatamente nos mesmos termos que se apresenta um precioso fragmento atribuído ao poeta - "o parecer até sobre a verdade faz violência" (Edmonds, 1952, p. 327). Além disso, é bastante significativa a comparação feita por Platão logo em seguida no diálogo: "Devo delinear num círculo à minha volta, como fachada e forma exterior, um retrato (skiagraphían) da virtude e arrastar atrás de mim a raposa do muito sábio Arquíloco, cheia de astúcias e artifícios" (365c). A alusão à pintura ilusionista (skiagraphia) - preparando já a comparação que será realizada no livro $\mathrm{X}$ - e ao animal que, para os gregos, encarna a ambiguidade, coloca a doxa de Simônides definitivamente do lado da apaté, em ruptura com a alétheia da poesia antiga. Ao conceber a arte poética como uma arte da ilusão como a pintura, 
como uma arte de enganar e de seduzir por meio de "imagens", Simônides prefigura "uma das grandes vias que dividem a história da problemática da palavra"; ele antecipa, dessa maneira, toda uma importante corrente de pensamento: nada menos que aquela mesma desenvolvida pelos sofistas (Detienne, 1988, p. 61). Motivo bastante, sem dúvida, para situar a poesia de Simônides como um dos alvos de eleição da crítica platônica e, ao mesmo tempo, hipótese a ser pensada como justificativa da aproximação com a pintura levada a cabo por essa mesma crítica (República, X, 596d-598d).

Que o poeta de Ceos ocupa, efetivamente, um lugar de destaque no pensamento de Platão sobre a poesia, tal tese se vê ainda reforçada por outros cruzamentos que são possíveis de se estabelecer entre ambos. Segundo Suidas, Simônides era também conhecido como Melikertes, em razão da "doçura de seu estilo" (Edmonds, 1952, p. 249); o epíteto, como mostra Thayer (1976, p. 10), conduz a interessantes associações : "melikreton = bebida de mel e leite oferecida às potências do inferno, e.g., Odisséia, 10.519; meliktes = cantor; melitoessan = mel-doce"; e, para nosso caso em questão, trata-se de algo sugestivo o fato de Platão, em algumas oportunidades, empregar esse mesmo termo ao referir-se à poesia. No Íon, no primeiro longo discurso sobre a inspiração poética, ouvimos Sócrates declarar: "Pois os poetas nos dizem - não é? -, que, colhendo de fontes de mel (melirrúton) corrente de certos jardins e vales das Musas, eles nos trazem as melodias (méle); como as abelhas (mélittai), também eles assim voam" (534b) ${ }^{13}$.

Alguns encontram, nessa passagem, referências de Platão a Píndaro - "Se a sorte bem quis que minha mão soubesse cultivar

${ }^{13}$ Tradução de Cláudio Oliveira (Platão, 2011). 
o jardim privilegiado das Cárides" (Olímpicas, IX 26-27) - e a Aristófanes - "É aí que, semelhante a abelha, Frinico ia colher a ambrosia de seus versos ..." (Os Pássaros, 748-751) -; mas, o jogo de palavras empregado aqui pelo filósofo não nos desautoriza a suspeitar que ele também tivesse em mente o mais "doce" dos poetas.

Ao lado e mesmo acima dessa doçura característica de seus versos, algumas fontes apontam para outra virtude estilística de Simônides: de acordo com Quintiliano, o poeta "deve ser elogiado pela escolha das expressões e por uma certa doçura; mas sua principal excelência reside em seu pathos; de fato, alguns críticos consideram que, nessa qualidade, ele supera todos os outros escritores dessa classe de literatura"; opinião semelhante à sustentada por Dionísio de Halicarnasso segundo o qual Simônides, ultrapassando até mesmo Píndaro nesse quesito, se notabilizaria antes por "sua expressão de compaixão (....), não por empregar o grande estilo mas por recorrer às emoções (pathetikos)" (Edmonds, 1952, p. 271). Na República, o problema da emoção se articula, de maneira decisiva, na crítica de Platão: é por dirigirse somente a ela, a essa parte inferior da alma em detrimento da razão, que a poesia, conduzindo à ruína psíquica de seus ouvintes, deveria ser definitivamente banida da cidade ideal.

Ao conceber a poesia como arte de produzir imagens, como arte da apaté tal qual a pintura, Simônides foi reconhecido, a justo título, como sendo o primeiro teórico da mimésis. De acordo com Detienne, ele "marca o momento em que o homem grego descobre a imagem", ele seria mesmo o "primeiro testemunho da teoria da imagem" (Detienne, 1988, p. 109). Mas, é segundo um ponto de vista diferente, dessa vez mais prático do que teórico, que se pode encontrar em Simônides um outro sen- 
tido da mimésis que também será tematizado e condenado por Platão. Como lembra Thayer, Simônides ganhou fama como líder de uma forma tradicional de poesia, a ode coral, na qual o poeta conduzia um coro de dançarinos e cantores.

O papel performativo do líder, dos músicos e do coro assume vários arranjos e padrões. Mas, a relação do líder como poeta e professor e seu coro podia ser carregada de intensidade hipnótica. Eles o imitam assim como ele, através de seu canto, pode imitar as ações dos homens e outros eventos incluindo os sons de animais, o vento, o grito dos pássaros (Thayer, 1976, p. 16).

Trata-se, portanto, daquela mesma mimésis apresentada na República que se propunha a imitar tudo indistintamente, "trovões, rumor do vento e do granizo, ruído do eixos e das roldanas dos carros e som de trombetas, flautas, siringes e de todos os instrumentos e ainda a voz de cães, ovelhas e pássaros" (397a)mimésis múltipla que, no livro III, Platão queria ver longe de sua cidade e de seus guardiães.

Com Schuhl, dizíamos de início que o "arcaísmo" ou o suposto conservadorismo do fundador da Academia constituía a outra face de seu misoneísmo, de sua ojeriza a tudo o que diz respeito à mudança, a toda inovação, identificada à decadência, não importando o domínio em que ela pudesse se manifestar. É nesse sentido que se pôde entender as severas censuras de Platão às artes plásticas como sendo dirigidas somente à arte ilusionista de seu tempo. Tentamos mostrar que, com Simônides à vista, essa mesma atitude crítica podia se estender também às inovações radicais que haviam sido implementadas no campo 
da atividade poética, à "nova" poesia concebida como uma techné laicizada destinada a enganar e a seduzir, como a pintura, através da produção de imagens.

Não só na República, mas também no Íon, é possível localizar a manifestação dessa tendência arcaizante, na medida em que Platão "sacraliza" a poesia definindo-a, em aparente sintonia com a tradição, como um dom divino, como fruto da possessão por um deus. Mas, com esse gesto, o filósofo buscava, no fundo, desqualificar qualquer pretensão da poesia ao estatuto de techné ou, em outros termos, combatia precisamente aquilo que Simônides havia reivindicado à sua própria arte. É verdade que, na República e, principalmente, no Sofista, a postura de Platão parece se modificar, ao admitir, desta feita, uma techné poética; porém, ao defini-la como mimésis e compará-la à pintura, o filósofo faz mais do que desenvolver uma argumentação de ordem abstrata: refere-se a uma nova maneira de se fazer e de se conceber a poesia - "pintura que fala", como a faz e a concebe esse precursor de Górgias.

\section{Referências bibliográficas}

COLIN, G. "Platon et la poésie". Revue des Études Grecques, tomo XLI, ano 1928, pp. 1-72.

COLlingWOOD R. G. "Plato's Philosophy of Art". Mind, New Series, vol.34, n.134 (April 1925), 154-172.

DETIENNE, M. Os mestres da verdade na Grécia Arcaica. Tradução de Andréa Daher. Rio de Janeiro: Zahar, 1988.

DUCHEMIN, J. "Platon et l'héritage de la poésie". Revue des Études Grecques, tomo LXVIII, ano 1955, p. 12-37.

LAERCIO, D. Vidas e Doutrinas dos Filósofos Ilustres. Brasília: Editora UnB, 1988. 
EDMONDS, J. M. (ed.). Lyra Graeca II. The Loeb Classical Library. Londres: Harvard University Press, 1952.

GALİ, N. Poesía silenciosa, pintura que habla. Barcelona: Ed. El Acantilado, 1999.

GOLDSCHMIDT, V. Question Platoniciennes. Paris: Vrin, 1970.

HALLIWEL, S. (ed.). The Republic, book 10. Warminster: Aris Phillips Ltda, 1988.

HAVELOCK, E. Prefácio a Platão. Tradução de Ernid Dobránsky. Campinas: Papirus, 1996.

JOLY, H. Le renversement platonicien. Paris: Vrin, 1994.

KIRK, G. S. e RAVEN, J. E. Os filósofos pré-socráticos. Lisboa: Fundação Calouste Gulbenkian, 1990.

NIETZSCHE, F. O Nascimento da Tragédia, ou Helenismo e Pessimismo.tradução Paulo César de Souza. São Paulo: Cia das Letras, 1992.

PlatÂO. A República. Tradução de Anna Lia Amaral de Almeida Prado. São Paulo: Martins Fontes, 2009.

_-_. A República, livro X. Tradução, ensaio e comentário crítico de Daniel Lopes. Universidade de Campinas: 2002, dissertação de mestrado.

. Íon. Introdução, tradução e notas de Cláudio Oliveira. Belo Horizonte: Autêntica, 2011.

SCHUHL, P.-M. Platão e a arte de seu tempo. Tradução de Adriano Machado Ribeiro. São Paulo: Discurso Editorial/Barcarolla, 2010.

THAYER, H. S."Plato's Quarrel with Poetry: Simonides". Journal of History of Ideas, vol. 36, No 1 (Jan.-Mar., 1975), p. 19-26.

VERNANT, J.-P. L'individu, la mort, l'amour: soi-même et 
l'autre en Grèce ancienne. Paris: Gallimard, 1989. . Entre Mito e Política. São Paulo: Edusp, 2002 